\title{
Antibacterial Characterisation of Apis Honey on Gram Positive Human Pathogens
}

\author{
M. Bhushanam ${ }^{\text {** }}$ and S. Madhusudan ${ }^{2}$ \\ ${ }^{1}$ Department of Zoology, Maharani's Science College, Bangalore, India \\ ${ }^{2}$ Department of Biotechnology, Maharani's Science College, Bangalore, India \\ *Corresponding author
}

\section{Keywords \\ Honey, \\ Antibacterial properties, Physico- chemical property, Disc-diffusion technique \\ Article Info \\ Accepted: \\ 10 March 2019 \\ Available Online: \\ 10 April 2019}

\section{A B S T R A C T}

Honey is one of the oldest and best loved sweetening agents for foods and over the centuries, it has still retained a "natural image". The raw materials for the production of 'Floral honey' are nectar, a dilute solution of sugars found in the nectarines of the flowering plants. Henceforth, the honey is defined as the natural sweet substance produced by honeybees from the nectar of blossoms or from the secretion of living parts of plants or excretion of plant-sucking insects living on parts of plants, which honeybees collect, transform and combine with specific substances of their own, store and leave in the honey comb to ripen and mature. Honey is an easily digestible confectionary, containing a wide range of nutritiously important complementary elements. Besides having a high content of saccharides, there are also organic acids, amino acids, mineral matter, colors, aromatic substances and a trace amount of fats. Honey also contains very valuable but unstable compounds, such as enzymes, substances of hormonal character, vitamins, and few minor compounds. The medicinal use of honey in wound treatment is known, since diverse ancient civilizations. A wide range of microbial species have shown to be inhibited by honey. The aim of present study was to evaluate physico-chemical and antibacterial properties of various Apis honey from different biogeographic zones of Coorg Western Ghats, Karnataka. The selected strains of bacteria namely - Streptococcus sp., Staphylococcus sp., Bacillus sp. and Enterococcus sp. were studied against the dilutions of honey by Agar-disc diffusion technique. The honey samples of Coorg Western Ghats, exhibited relatively high antibacterial activity.

\section{Introduction}

Honey is the natural sweet substance produced by honeybees from the nectar of blossoms or from the secretion of living parts of plants or excretions of plant - sucking insects living on parts of plants, which honeybees collect, transform and combine with specific substances of their own store and leave in the honey comb to ripen and mature.

It is a complex mixture and presents very great variation in composition and characteristics due to its geographical and botanical origin. From ancient times, honey was used both as a natural sweetener and a 
healing agent (Crane, 1980; Ramirez et al., 2000), its main features depends on the floral origin or the nectar collected by the foraging bees. The composition and quality of honey also depends on several environmental factors during production such as weather and humidity inside the hive, nectar sugar concentration and treatment of honey during extraction and storage (Joseph et al., 2007). Honey is produced by different bee species during different seasons with different floral compositions, harvesting techniques and post harvest handling to a large extent results in difference in the quality of honey (Mahalaxmi, 1998).

Honey is an easily digestible food stuff that contains a range of nutritionally important compounds (Celechovoska and Vorlova, 2001). The major components of honey include various saccharides, water, amino acids, minerals, proteins, vitamins and unstable compounds such as enzymes (Qiu et $a l ., 1999)$. Honey is generally considered as a natural and healthy product (Reybroeck, 2003).

Karnataka produces 800 to 900 tons of honey annually. The characteristics of honey from different floral sources influence the commercial value and the consumer preferences (Shripad and Rangaswamy, 2001). Singh and Bath (1997) reported that flow behaviour, chemical composition and overall acceptability of Indian honey were dependant on the plant floral source from which the honey was elaborated.

After the emergence of pharmaceutical antibiotics, honey was rarely used as a treatment for open wounds. Continued use of traditional antimicrobials has resulted in selection of drug resistant bacteria. However, honey still appears to be effective against most microbes (Miorin et al., 2003; Kwakman et al., 2008; Henriques et al., 2011).

\section{Materials and Methods}

\section{Collection of honey samples}

The honey samples from the domestic bees viz., Apis cerana and A. mellifera and the wild honey bees like A. dorsata and A. florea were harvested, from different study areas of Coorg, Karnataka during December' 2017 to February' 2018. All the honey samples were aseptically collected by extracting from the bee hives. Each honey sample was first filtered with a sterile mesh to remove debris. All the samples were collected and transported in sterile sealed bottles or screwed cap tubes. Two replications of bottles for each samples were kept under storage at $2-8{ }^{0} \mathrm{C}$ until tested as per the method proposed by Nzeako and Hamdi (2000).

\section{Physical parameters of honey}

\section{Determination of $\mathrm{pH}$}

The $\mathrm{pH}$ is determined by using a digital $-\mathrm{pH}$ meter for $10 \% \mathrm{w} / \mathrm{v}$ honey solutions (Jyothi, 2006).

\section{Determination of moisture content}

The water content is determined by digital refractometer (Bogdanov et al., 1999). The results were expressed in percentages.

\section{Chemical parameters of honey}

\section{Determination of reducing sugars}

The reducing sugars were to be estimated by the method of soxhlets modification of Fehling's solution by titration of the boiling point against solution of reducing sugars of honey using methylene blue as an internal indicator (Codex Alimentaries Commission, 2001). The results were expressed in percentages. 
Determination of non-reducing sugars (sucrose) in honey

The non - reducing sugars were determined according to the method followed by Anonymous (1994) and BIS (1994). The results were expressed in percentages.

\section{Determination of HMF (Hydroxy methyl furfural)}

HMF is extracted with ethyl acetate and colour measurement was determined with resorcinol (White et al., 1988). The results were expressed in $\mathrm{mg} / \mathrm{kg}$.

\section{Determination of peroxide (glucose oxidize)}

The peroxide content is sequenced with peroxide test strips (Jyothi, 2006). The results were expressed in $\mu \mathrm{g} / \mathrm{g} / \mathrm{h}$ at $20^{\circ} \mathrm{C}$.

\section{Determination of total ash content}

The ash contents are analysed using the method as described by Celechovoska and Vorlova, 2001. The results were expressed in percentages.

Analysis of antibacterial potentiality of honey

\section{Collection of bacterial strains}

The test organisms Staphylococcus aureus, Enterococcus, Streptococcus sp. and Bacillus subtilis, used in the present study were collected from the Department of Microbiology, Maharani's Science College for Women, Bangalore, Karnataka, India.

\section{Pathogen/microbial culture in In-Vitro conditions}

\section{Sub culture of microbial strains}

The collected strains of bacteria were initially sub cultured on Nutrient Agar slants by slantstreak method and incubated at $37^{\circ} \mathrm{C}$ for $24 \mathrm{~h}$.
Sub culturing of Microbial strains on Nutrient broth medium

A loop of bacterial strains is inoculated into a sterile test tube containing a sterile nutrient broth medium (in a laminar air flow), under sterile conditions. The $\mathrm{pH}$ is adjusted to $7.2 \pm 0.1$ and sterilezed at $15 \mathrm{lbs}$ for $15-20$ minutes using an autoclave. The sterile tubes were to be incubated at $37^{\circ} \mathrm{C} 24 \mathrm{~h}$.

\section{Culturing of bacterial strains on plates by pour plate method}

The sensitized Nutrient Agar medium is poured into the sterile plates of $250 \mathrm{~mm} \mathrm{X}$ $250 \mathrm{~mm}$ size and cooled within the chamber of LAF. The pathological suspension of $50 \mu 1$ from nutrient broth culture is spread over the medium using a sterile glass spreader in incubation at $37^{\circ} \mathrm{C}$ for $24 \mathrm{~h}$.

\section{Agar disc diffusion assay}

Muller Hinton agar was prepared and poured into sterile petridish (about 15-20ml) aseptically and allowed to solidify. In this method, for each honey, three sets of eight Muller Hinton agar plates were set out, each set was then inoculated with one species of bacteria. Each agar plate was inoculated with bacteria by dipping sterile swabs into inoculum, draining it and swabbing aseptically. Sterile paper discs $(6 \mathrm{~mm})$ were dipped in different dilution of honey, drained and placed on swab plates, the plates were left to dry for 15 minutes, to provide time for the test material to diffuse into the medium and finally incubated at $37^{\circ} \mathrm{C}$ for 16 hours. Standard antibiotic discs of chloramphenicol, tetracycline and ciprofloxacin were used on the inoculated plates for comparison. The amount of inhibition was recorded by measuring the diameter of the zone of inhibition, in millimetres ( $\mathrm{mm}$ ) using a vernier scale. The measurement included the 
diameter of the absorbent disc. The data obtained is subjected to F-test (Levy and Marshall, 2004; Bilal et al., 1998).

\section{Results and Discussion}

\section{Physico-chemical parameters}

The study has successfully generated visible and tangible results by the application of standard methods of apiculture, biochemistry and microbiology. Experimental results obtained in the present study were very much supported to the chosen objectives.

Each experiment was done in triplicate to get an average result of the antibacterial activity of honey; the two statistical methods were used in analysing the results, the mean (x) and Standard Deviation (SD). Results were significant at $\mathrm{p}>0.05$ level.

Ash/ Mineral contents varied from $0.11 \pm 0.3 \%$ to $0.59 \pm 0.1 \%$ with an average of $0.2 \pm 0.1 \%$. moisture content depends on the environmental conditions and the beekeepers manipulation at the harvest period (BIS, 1994). The results showed no significant differences between the samples for moisture content. The moisture contents ranged between $13.7 \pm 3.3 \%$ and $20.3 \pm 0.1 \%$ with an average value of $15.2 \pm 2.1 \%$.

The $\mathrm{pH}$ of the different Apis honey samples tested ranged between $3.4 \pm 0.2$ to $6.3 \pm 0.0$, there was no significant difference observed. The results obtained for the HMF were significantly different between the types of Apis honey samples tested. HMF value ranged between $8.6 \pm 0.7$ to $14.7 \pm 0.2 \mathrm{mg} / \mathrm{Kg}$. The peroxide content in the different Apis honey samples tested ranged between $8.1 \pm 0.4$ to $16.9 \pm 0.3 \mathrm{ug} / \mathrm{g} / \mathrm{hr}$ at $20{ }^{\circ} \mathrm{C}$.

No significant differences in sucrose and reducing sugar contents were observed in samples. The sucrose (\%) in the different Apis honey samples tested ranged between $0.9 \pm 0.3$ to $6.5 \pm 1.3 \%$ and the reducing sugars $(\%)$ ranged between $63.3 \pm 4.9 \%$ to $82.3 \pm 3.7 \%$.

\section{Antibacterial activity}

Standard antibiotic discs of Chloramphemical $\left(\mathrm{c}^{30}\right)$, tetracycline $\left(\mathrm{TE}^{30}\right)$ and Ciprofloxacin $\left(\mathrm{CIP}^{5}\right)$ were used on the inoculated plates for comparision of sensitivity for all the honey samples. The antibiotic discs commercially available were used. The diameter of the zone of inhibition produced around the discs and all the samples of honey was measured by Vernier scale.

The inhibition zone diameter (IZD) of different Apis honey samples were determined using different concentrations (50-100\%) for the test organisms Bacillus sp, Staphylococcus aureus, Enterococcus and Streptococcus sp. All the honey concentrations showed different levels of growth inhibition on all the bacteria tested. The diameter of zone of inhibition increases as the concentration of honey also increases.

The results of the in vitro antibacterial effects of honey of Apis cerana against the different bacteria tested by disc diffusion test are shown in Figure 1. The results showed that honey exhibited a fairly good antibacterial activity against Gram positive bacteria.

The results of the invitro susceptibility of the test organisms to Apis florea honey sample by disc diffusion test are represented in Figure 1. In all the cases of microorganisms tested, net honey concentration produced greater IZD $45.6 \pm 0.1 \mathrm{~mm}$ for Staphylococcus aureus. and $33.8 \pm 0.1 \mathrm{~mm}$ for Bacillus sp.

The results of the invitro susceptibility of the test organisms to Apis dorsata honey sample by disc diffusion test are represented in Figure 
1. In all the cases of microorganisms tested, net honey concentration produced greater IZD $40.3 \pm 0.1 \mathrm{~mm}$ for Enterococcus sp. and $40.1 \pm 0.01 \mathrm{~mm}$ for Streptococcus sp. All the tested bacteria were susceptible to the honey; the IZD produced was significantly broader at all the honey concentration ranging from 50 $100 \%$.

The results of the invitro susceptibility of test organisms to Apis mellifera honey sample by disc diffusion test are represented in Figure 1. In all the cases of microorganisms tested, net honey concentration produced greater IZD $39.3 \pm 0.1 \mathrm{~mm}$ for $S$. aureus and $31.4 \pm 0.08 \mathrm{~mm}$ for Enterococcus sp. All the tested bacteria were susceptible to the honey, the IZD produced was significantly broader at all the honey concentration ranging from $50-100 \%$.

The honey of Apis cerana showed greater antibacterial effect against $S$. aureus than Bacillus sp. The highest inhibition zone was recorded against $S$. aureus $(39 \pm 0.7 \mathrm{~mm})$ at $100 \%$ concentration, while Enterococcus $s p$. showed slightly lower $I Z D(31 \pm 0.1 \mathrm{~mm})$ at the same concentration.

As shown in Figure 1, all the tested bacteria were susceptible to the honey, the IZD produced was significantly broader at all the honey concentration ranging from $50-100 \%$ dilutions (Table 1).

Table.1 Physico-chemical parameters of honey (Mean \pm S.D)

\begin{tabular}{|c|c|c|c|c|c|c|c|}
\hline $\begin{array}{c}\text { Honey } \\
\text { types }\end{array}$ & $\begin{array}{c}\text { Reducing } \\
\text { sugars } \\
(\mathbf{\%})\end{array}$ & $\begin{array}{c}\text { Sucrose } \\
(\mathbf{\%})\end{array}$ & $\begin{array}{c}\text { Peroxide } \\
\text { content } \\
\mathbf{u g} / \mathbf{g} / \mathbf{h r} \text { at 20 }\end{array}$ & $\begin{array}{c}\text { HMF } \\
\text { content } \\
(\mathbf{m g} / \mathbf{K g})\end{array}$ & $\begin{array}{c}\text { Ash } \\
\text { content } \\
(\boldsymbol{\%})\end{array}$ & $\begin{array}{c}\text { Moisture } \\
\text { content } \\
(\boldsymbol{\%})\end{array}$ & $\mathbf{p H}$ \\
\hline $\begin{array}{c}\text { Apis } \\
\text { florea }\end{array}$ & $82.3 \pm 3.7$ & $0.9 \pm 0.3$ & $16.9 \pm 0.3$ & $14.7 \pm 0.2$ & $0.59 \pm 0.1$ & $13.7 \pm 3.3$ & $3.4 \pm 0.2$ \\
\hline $\begin{array}{c}\text { Apis } \\
\text { dorsata }\end{array}$ & $73.9 \pm 4.1$ & $2.3 \pm 0.1$ & $9.5 \pm 0.5$ & $8.8 \pm 0.8$ & $0.12 \pm 0.2$ & $18.9 \pm 3.7$ & $5.7 \pm 1.6$ \\
\hline $\begin{array}{c}\text { Apis } \\
\text { mellifera }\end{array}$ & $68.8 \pm 2.7$ & $4.1 \pm 1.5$ & $8.7 \pm 0.2$ & $8.6 \pm 0.9$ & $0.12 \pm 0.1$ & $19.1 \pm 1.9$ & $5.9 \pm 0.3$ \\
\hline Apis cerana & $63.3 \pm 4.9$ & $6.5 \pm 1.3$ & $8.1 \pm 0.4$ & $8.6 \pm 0.7$ & $0.11 \pm 0.3$ & $20.3 \pm 0.1$ & $6.3 \pm 0.0$ \\
\hline
\end{tabular}

Significant at $\mathrm{p}>0.05$

Fig.1 Antibacterial activity of Apis honey

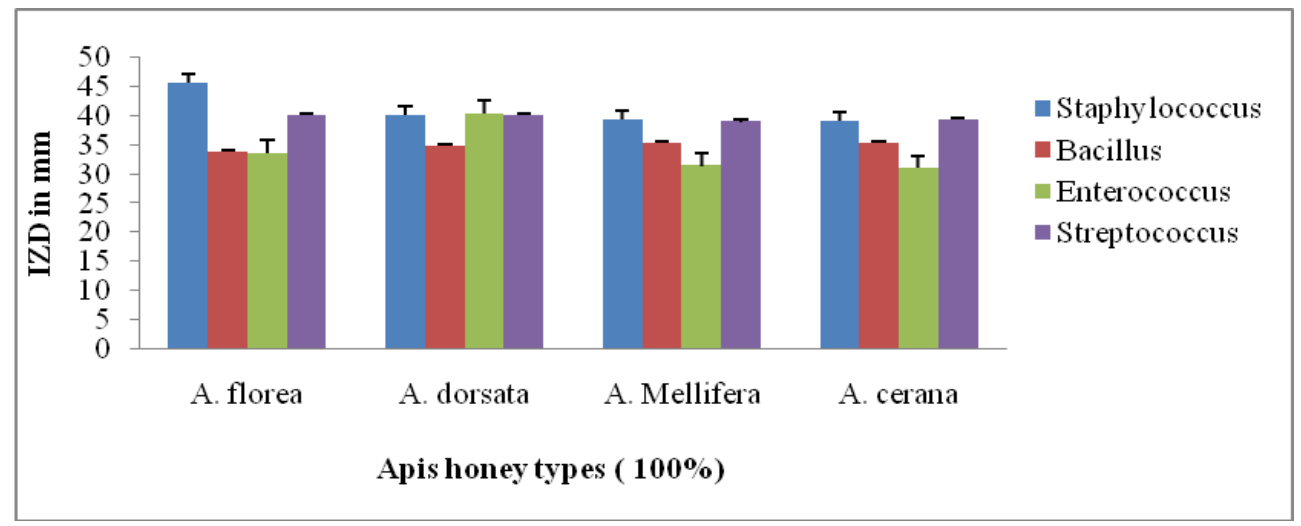


Antimicrobial agents are essentially important in reducing the global burden of infectious diseases. However, as resistant pathogens develop and spread, the effectiveness of the antibiotics is diminished. This type of bacterial resistance to the antimicrobial agents poses a very serious threat to public health and all kinds of antibiotics, including the major last-resort drugs, as the frequencies of resistance are increased worldwide (Levy and Marshall, 2004; Reybrock, 2003). It is well established that honey inhibits a broad spectrum of bacterial species. More recently, honey has been reported to have an inhibitory effect to around 60 species of bacteria including aerobes and anaerobes, Gram positives, and Gram negatives (Hannan et al., 2004).

In thestudy, different Apis honey samples were tested for their antimicrobial activity on Gram positive strains of bacteria. The study showed varying degree of in vitro growth inhibition activity of Apis honey against the tested organisms. These were due to the effect of $\mathrm{pH}$, and the sensitivity of these organisms to hydrogen peroxide which are unsuitable for bacterial growth, represented as an inhibition factor in honey (Minisha and Shyamapada, 2011). All the different concentrations of different Apis honey samples (50 to 100\%) showed growth inhibitory activity against all the tested bacteria. Variations seen in overall antibacterial activity were due to changes in the level of hydrogen peroxide achieved. The results further showed that there was an increase of inhibition zone for the tested microorganisms with increase in the concentration of honey. This was obvious by statistical analysis which revealed that there was significant difference in the values between the different honey concentrations.

The honey showed strongest inhibitory activity against $S$. aureus and Enterococcus $s p$. This shows that the tested honey has antibacterial activity. Significant inhibition of growth of all the tested Gram positive bacteria was observed at all concentration. These results are in agreement with Bilal et al., (1998) who found that honey inhibited the growth of S. aureus, E. coli and Pseudomonas sp., thus showing that honey exhibited a fairly good antimicrobial activity against Grampositive bacteria. The antimicrobial activity of bee honey has been attributed to several properties of honey, including its osmotic effect, its natural low $\mathrm{pH}$, and the production of hydrogen peroxide, as also the presence of phenolic acids, lysozyme, and flavanoids (Abd-El Aal et al., 2007). The honey used in this study were effective against Streptococcus., Entrococcus sp., Bacillus and Staphylococcus aureus. These findings are in accordance with several earlier reports on antibacterial activity of honey from other countries (Melissa et al., 2004). Among all the Apis honey samples tested Apis florea showed high degree of sensitivity against tested bacteria followed by Apis cerana.

Honey has been shown convincing potent antibacterial activity. The activity seen with dilute solutions of honey clearly indicates that there is much more than the high sugar content of honey involved in its antibacterial action. Significant differences were found between the honey under study for almost all the physicochemical parameters. The values of quality parameters for all the honey samples studied coincide with those specified by the international honey regulations.

In conclusion, the honey samples of Apis used in the present study has been shown to exhibit antibacterial activity when tested in vitro. The honey has been shown to prevent the growth of a wide range of potential human pathogens and therefore has a broad-spectrum of antibacterial activity. Disc diffusion method is a very useful tool to evaluate effectiveness of natural antibiotics. 


\section{References}

Abd-El Aal A. M., El-Hadidy M.R., ElMashad N.B., and El-Sebaie A.H. 2007. Antimicrobial effect of bee honey in comparison to antibiotics on organisms isolated from infected burns. Ann. Burns Fire Disas., XX(2):83-88. African J. Biotech. 6(7): $908-913$.

Anonymous. 1994. World honey market. Amer. Bee J. 134.

Bilal, A.N., Molan, P.C., and Sallal A.K. 1998. Antimicrobial activity of honey on selected microorganisms: A preliminary study. Biomed. Res. (India). 9:51-54.

BIS. 1994. Indian Standard Specification for extracted honey (Second Revision), IS: 4941;1994, Indian Standard Institution, New Delhi, p: 10.

Bogdanov, S., Lullman, C. and Martin, P. 1999. Honey Qualaity and international regulatory standards. Review of the work of the International Honey Commission, Mitt. Gebiete Lebensm. Hyg. 90:108125.

Celechovska, O. and Vorlova, L. 2001. Groups of Honey-physicochemical properties and heavy metals, Acta, Vet. BRNO. 70:91-95.

Codex Alimentarius Commission. 2001. Codex standards for sugars (honey). Supplement 2 to Codex Alimentarius volume III. Food and Agriculture Organisation of the United Nations and World Health Organisation, Rome.

Crane, E. 1980. A book of honey, Oxford University press, Oxford, U.K. p 198.

Hannan, A., Barkaat, M., Saleem, S., Usman, M., and Gilani, W.A., 2004. Manuka honey and its antimicrobial potential against multi drug resistant strains of Typhoidal salmonellae, Ph.D. thesis,
Department of Microbiology, University of Health Science, Lahore, Pakistan.

Henriques, A.F., Jenkins, R.E., Burton, N.F., and Cooper, R.A. 2011. The effect of manuka honey on the structure of Pseudomonas aeruginosa. Eur J Clin Microbiol Infect Dis. 30:167-171.

Joseph, T., Awah - Ndukum Julius, Flarence. A., Dongock N., Delphine, Pinta Jonnas and Mvondo Ze Antoine. 2007. Physico - Chemical and Microbiological characteristics of honey from the Sudano- guinean zone of West Cameroon, African J. Biotechnol., 6(7): 908-913.

Jyothi, J. V. A. 2006. Physico-Chemcal Analysis of honey of different honeybees, Apis erana, Apis dorsata, Apis mellifera and Apis florea. J. Ent. Res.30 (1): 43-45.

Kwakman, P.H.S, Van den Akker J., Güçlü A., Aslami H., Binnekade J.M., de Boer L., Boszhard L., Paulus F., Middelhoek P., te Velde A.A., Vandenbroucke-Grauls C.M.J.E., Schultz M.J., Zaat S.A.J. 2008. Medical-grade honey kills antibioticresistant bacteria in vitro and eradicates skin colonization. Clin Infect Dis. 46:1677-1682.

Levy, S.B., Marshall, B. 2004. Antibacterial resistance worldwide: causes, challenges and responses. Nat. Med. 10:122-129.

Mahalaxmi Shreshtha. 1998. Physical and Chemical properties of Nepalese honey, Proc. of $4^{\text {th }}$ Asian Apicultural Association, Int. Conf. Kathmandu, pp 137-139.

Melissa, A. M., Olga, I.P.Z., and Randy, W.W. 2004. Growth inhibition of food borne pathogens and food spoilage organisms by select raw honeys. Inter. J. Fd Microbiol., 97:1-8.

Minisha, D.M., and Shyamapada, M. 2011. 
Honey: its medicinal property and antibacterial activity. Asian Pacif. J. Trop. Biomed. pp. 154-160.

Miorin, P.L., Levy Junior, N.C., Custodio, A.R., Bretz, W.A., and Marcucci, M.C. 2003. Antibacterial activity of honey and propolis from Apis mellifera and Tetragonisca angustula against Staphylococcus aureus. J Appl Microbiol. 95:913-920.

Nzeako, B. C. and Hamdi, J. 2000. Antimicrobial potential of honey on some microbial isolates, Med. Sci. 2: 75-79.

Qiu, P. Y., Ding, H. B. Tang, Y. K. and XU, R. J. 1999. Determination of Chemical Composition of Commercial honey by near infrared spectroscopy. J. Agric. Food Chem. 47: 2760 - 2765.

Ramirez Cervantes, M. A., Gonzales Novelo, S. A. and Saure Duch, E. 2000. Effect of the temporary thermic treatment of honey on variation of the quality of the same during storage. Apiacta, 35: $162-170$.

Reybroeck, W. 2003. Residues of Antibiotics and Sulphonamides in Honey on the Belgian Market. J. Apiacta 1:50.

Shripad, N., Agashe and Ranga Swamy, B. E. 2001. Chemical Characterisation of Apis cerana $F$. and Apis dorsata $F$. Honey from Dakshina Kannada, Karnataka (India), Indian Bee J. 63 (3\&4); $15-20$.

Singh, N. and Bath, K. P. 1997. Quality evaluation of different types of India honeys. Food chem. 58 (1-2):129-133.

White, J. W., Subers, M. H. and Schepartz, A. I. 1988. The identification of inhibine, the antibacterial factor in honey, as hydrogen peroxide and its origin in a honey glucose-oxidase system. Biochem. Biophys. Acta, 73: 57-70.

\section{How to cite this article:}

Bhushanam, M. and Madhusudan, S. 2019. Antibacterial Characterisation of Apis Honey on Gram Positive Human Pathogens. Int.J.Curr.Microbiol.App.Sci. 8(04): 932-939. doi: https://doi.org/10.20546/ijcmas.2019.804.107 